\title{
オフセット輪転印刷に発生する特殊なゴースト現象と印刷用紙の関係調査
}

\author{
三菱製紙株式会社 総合研究所 鷲谷公人，柴 裕一，西 哲哉
}

\section{A Study of the Relationship between Coated Papers and Reverse-Image Ghosting}

Kimito Washiya, Yuichi Shiba and

Tetsuya Nishi

Corporate Research Center,

Mitsubishi Paper Mills Limited

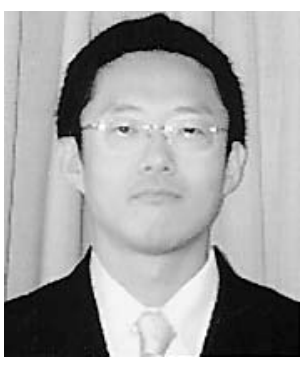

熟谷公人

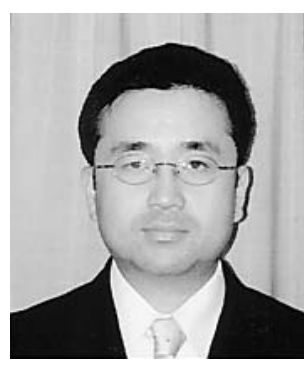

柴 裕一

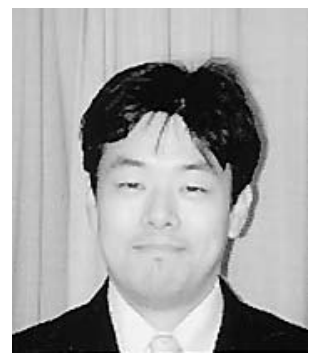

西 哲哉

Reverse-image ghosting is one of the ink transfer errors that occurs during web-fed offset printing. It happens when the imaging area on the face and the back are not balanced. This paper report what properties of coated paper influence reverse-image ghosting. Reverse-image ghosting was not influenced by water absorptiveness, stiffness or picking intensity. However, smoothness had a comparatively strong relationship with ghosting. In particular, dynamic (PPS) roughness under $20 \mathrm{kgf} / \mathrm{cm}^{2}$ of hard backing was strongly related to it. And in the case of the same PPS roughness, ink receptivity was related to ghosting. These results support the idea that reverse-image ghosting is caused by improper web release of paper, which leads to ink piling on the blanket cylinder and ultimately to reverse-image ghosting.

Keywords : offset printing, ghosting, coated paper, delamination, reverse-image ghosting 分類： $Y_{8}$ 印刷, $S_{5}$ 塗工印刷用紙（微塗工印刷用紙含む）

\section{1. 緒言}

\section{1 背 景}

オフセット (平版) 印刷，凸版印刷，凹版印刷，孔 版印刷の 4 大方式に代表される商業印刷は世の中に広 く用いられている。紙の使用量の約半分はこれらの印 刷に用いられる印刷用紙であり, その需要はデジタル 全盛の今でもな挑び続けている。

これらの印刷方法の中でもオフセット印刷は商業印 刷の主流として用いられている。経済的で製版が容易
であること，大サイズの印刷がしやすいことがその理 由であろう。

オフセット印刷の中でも輪転式印刷 (以下，オフ輪) は，ひじわに代表されるような品質面の問題が存在し， 枚葉式印刷よりも印刷品質としては劣るとされている。 さらに，印刷トラブル発生時の損紙の量も多い。しか し, 巻き取り紙のまま印刷し, インキを強制乾燥させ ることが出来るので, 他の印刷方式に比べその印刷速 度は圧倒的に速く ${ }^{1)}$, しかも印刷後, 折り助み, 裁断 もオンラインで行うことが出来るというメリットもあ 
り，生産性，経済性で極めて優れた方式である。その ため, オフセット印刷市場では枚葉からオフ輪へとシ フトしつつある。これらの背景から，オフ輪印刷の品 質向上や印刷トラブルの防止は今後も非常に重要な課 題である。

オフ輪印刷における問題点には様々な種類があり ${ }^{2)}$, その中で，印刷用紙が関与するトラブルには，ひじわ， ゴーストがある。ひじわは強熱乾燥による紙の収縮に より ${ }^{3)}$ そしてゴーストは版のバランスが悪いときに インキの供給不具合によって起こる1)。これらのトラ ブルは, 発生機構が複雑で $100 \%$ 防止する手段がない ため問題視されているが，現在までの努力により原因 が理解され，ある程度対処法が見いだされてきた。

\section{2 特殊なゴースト現象について}

ところが，ゴースト現象の中には発生機構が特殊な 事例が存在する(1) -6)。この現象では Fig. 1-a, Fig. 1-b に示すように印刷画像（image A）にないはずの模様 (文字や画像) がぼんやりと白抜けして現れる（image B)。この現象は日本のオフ輪印刷関係者には広く知 られている現象だが，名称ははっきりと定義されてい

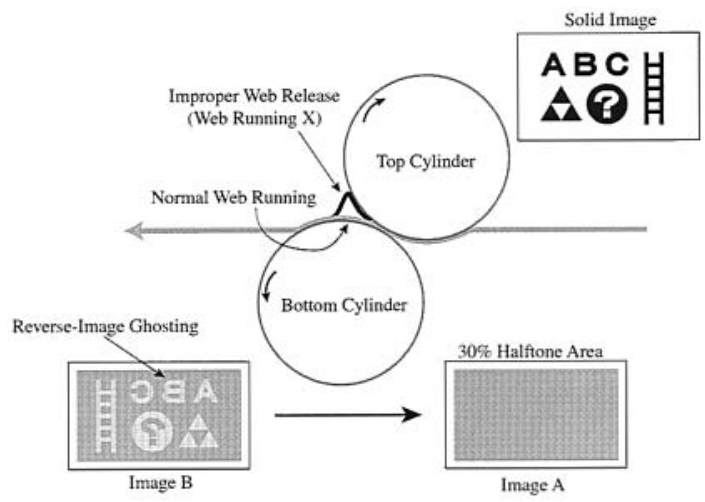

Fig. 1-a (upper side) Proposed mechanism of reverse-image ghosting.

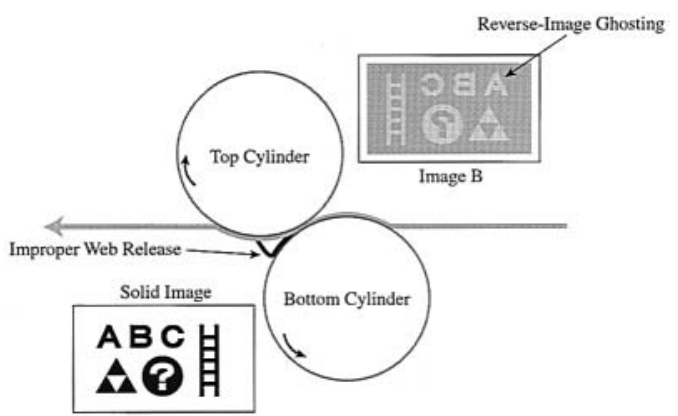

Fig. 1-b（lower side） Opposite arrangement
るわけではなく，通称「デラミゴースト」と呼ばれて いる。

藤田らはその発生機構を詳細に解析し, 本現象が用 紙のデラミネーション（ばたつき）とインキのパイリ ングに起因することを見いだしている豆。そのため名 称をデラミゴーストかインキパイリングゴーストと呼 ぶべきと提唱しているが，本論文中では紙面の都合上 「デラミゴースト」に統一する。また，海外ではこの 現象はあまり認識されていないようで, 英語表記もは っきりしないが，米国 Tappi 関係者の指摘に従い Reverse-image ghosting と標記することとした。

デラミゴーストは BB 型のオフ輪印刷機で, 表裏の 版のバランスが悪いときに起こる。BB 型のオフ輪印 刷機では Fig. 1-a，Fig. 1-b の様にブランケットシリ ンダー（以下， $\mathrm{BC}$ ) の上下が進行方向に対してずれ て配置している（スタッカード配列, Fig. 1-a, Fig. 1bではかなり㻅張してあり, 実際のずれは $5^{\circ}$ 程度で ある)。デラミゴーストは，用紙の上流側の $\mathrm{BC}(\mathrm{Top})$ に軽い(網点面積率の小さい) 画像, 下流側の $\mathrm{BC}$ (Bottom）に重い（網点面積率の大きい）画像が配置され る，アンバランスな場合に発生しやすい。

Fig. 1-a, Fig. 1-bの例では, 用紙の進行方向に対 して上流側の BCに $100 \%$ の濃度の絵柄 (または文字) があり, 下流側の BCに $30 \%$ の濃度の長方形の絵柄 がある。これを印刷していくと, 長方形部分に Top 側の画像部の真裏だけが薄くなって現れる（image B)。 これがデラミゴーストであり，一種のインキ付き不良 である。Photo.1-a には実際に発生したデラミゴース トの写真を, Photo. 1-bには比較として通常の写真を 示した。

\section{3 デラミゴーストの推定発生機構}

この現象は, インキタックによって BCに用紙が過 度に貼り付き, Fig. 1-a 中の Web Running Xのよう な用紙の走行不良（デラミネーション）を誘発し，そ の結果起こる下側の $\mathrm{BC}$ と用紙の接触不良が原因と推 察されている。発生するのは用紙の走行方向に対し上 流側の BC に重たい画像，下流側に軽い画像の組み合 わせがある時のみであり, Fig. 1-a では下側に発生す るが， BC 配置が逆の Fig. 1-b では上側に発生する。 また上下画像が逆配置の場合は発生しない。

また，デラミゴーストは画像のバランスが悪い場合 でも，印刷の初期から発生するわけではなく，印刷を 開始して, 一定時間後に現れることが多く, 用紙の走 行不良だけが直接の原因とは言えない。デラミゴース トが発生したとき，発生した側の BCにはゴースト画 像と同様のインキ層が現れる (Fig. 2)。藤田らの研 


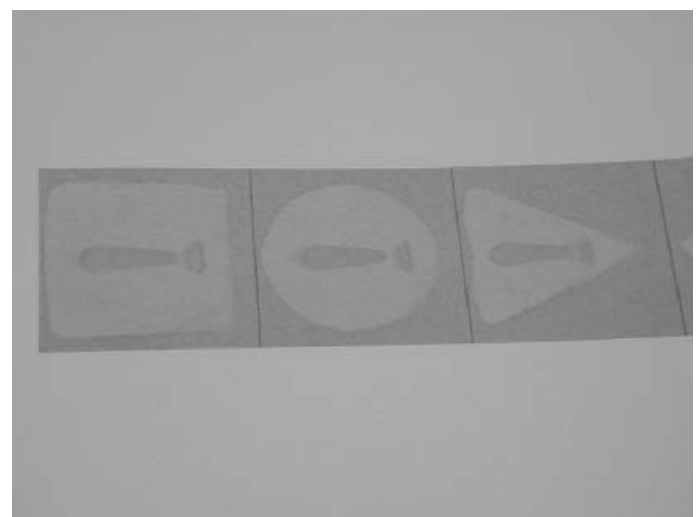

Photo. 1-a Reverse-image ghosting.

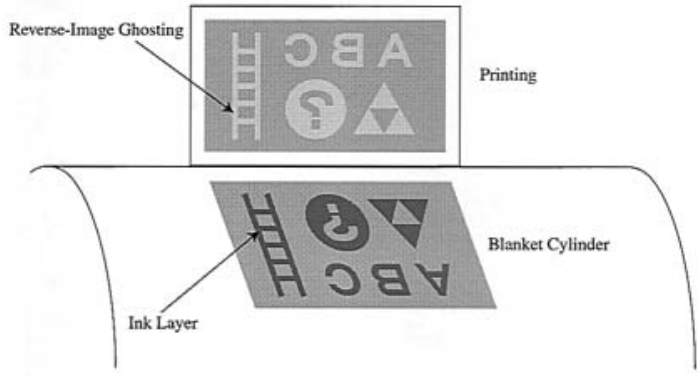

Fig. 2 Ink layer on the blanket cylinder.

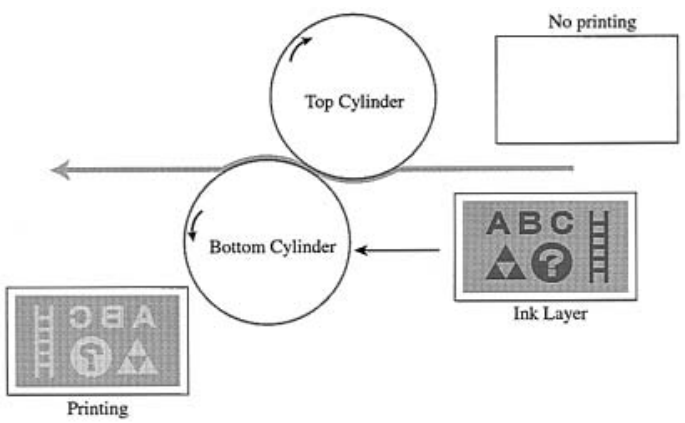

Fig. 3 The examination reported by Fujita ${ }^{6}$. It indicates that the ink layer is directly involved in reverse-image ghosting.

究によれば，インキ層が現れたあとに反対側の画像を 取り去ってもゴーストが継続して発生し続けることか ら (Fig. 3) ${ }^{6}$ このインキ層が直接の原因と言える。 Photo. 2 には実際に発生したインキ層の写真を示す。 まとめると，用紙の走行不良がインキの転写不良を誘 発し (Fig.4)，インキの転写不良によってインキ層 が蓄積し, デラミゴーストが発生すると推察される。

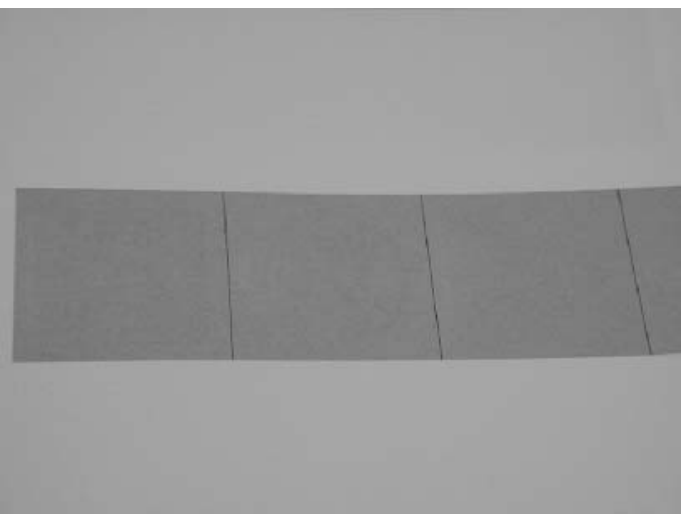

Photo. 1-b Normal printing.

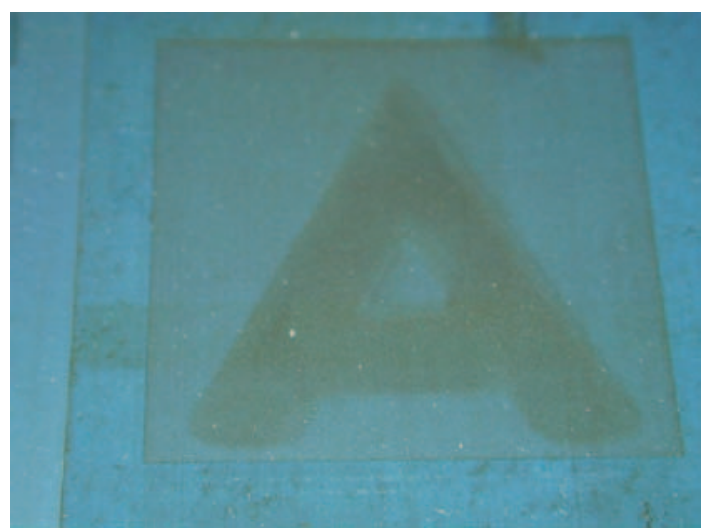

Photo. 2 Ink layer piling.

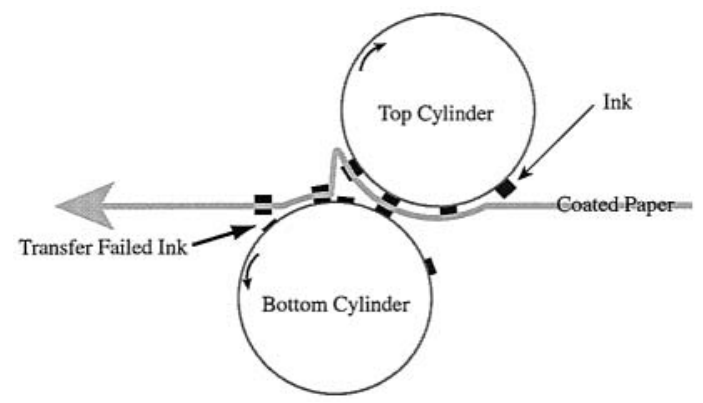

Fig. 4 Proposed ink layer piling mechanism.

オフ輪印刷の場合，常に同じ $\mathrm{BC}$ の位置に同じ画像 が転写される。このため用紙の走行不良は常に同じ画 像位置，言い換えれば常に同じ BC 位置で起こること になる。用紙の走行不良の際，画像の重たい側の方に 用紙が引っ張られるので，軽い画像の側でインクの転 写不良, 蓄積が発生する。よって, 軽い画像側でのみ デラミゴーズトが発生する。このように，現段階での 
推定機構はデラミゴーストの発生機構をうまく説明で きている。

\section{4 デラミゴーストの解決方法等について}

この現象の問題点は決定的な解決手段がないことに ある。画像のバランスを取るのが一番の解決策だが, 実際の商業印刷で画像に制限を加えるのは現実的では ない。 BC の粗面化, インキのタックを弱くするなど の方法も考えられるが，これらの条件も印刷品質や印 刷作業性に極度に影響する。結局 BC の洗浄が最も現 実的な解決策であり, デラミゴーストが出るたびにこ の作業を行って対応するしかない。

基本的には絵柄, 印刷機, インキの要因が強い現象 ではあるが，用紙も明らかに影響を与えている。なぜ なら, 近年グロス塗工紙の白紙光沢は非常に高くなっ てきているが，これに伴いデラミゴーストの発生率が 増えている。厚物/薄物, グロス/マット, 微塗工/A 3/A 2/アートなど紙の種類による発生頻度の違いも 認識されている。これまでこれらの影響について系統 的に検討された例はなく, 経験則に頼っているのが現 状である。そこで本研究では, デラミゴーストの発生 に影響を与える用紙の要因について詳細に解析を行っ たので報告する。

\section{2. 実験}

\section{1 実験方法}

特記しない限り, すべての資材, 試薬, 材料は市販 品をそのまま用いた。塗工液は一般的な手法で調整し た。

\section{2 塗工紙作製条件}

実験に先立ち, 用紙のデラミゴーストへの影響につ いて, その発生機構やオフ輪印刷関係者の助言を元に 関係する物性を推定した（Table 1)。これを元に様々 な物性の塗工紙を作製し (Table 2), オフ輪印刷を行 なった。

・塗料配合：Table 3

・塗工方式 : ブレード塗工

・坪量 : 74 $110 \mathrm{~g} / \mathrm{m}^{2}$

・カレンダー条件：スーパーカレンダー処理。サン プル No. 4 は低線圧処理。

\section{3 塗工紙物性評価方法}

・平滑度 : スムースター及びプリント・サーフ表面 粗さ試験機を用いて測定した。プリントサーフ試 験機ではハードバッキングを用いて測定した。

・こわさ（クラーク）：クラークこわさ試験機を用 いて測定した。

・不透明度：分光色彩・白度計を用いて測定した。

·透気抵抗度 : スムースター透気度計を用いて測定 した。

・印刷適性：RI 印刷試験器, 及びコーサー色濃度 計を用いて測定した（インキセット性, 吸油性, 吸水性, ピック強度)。

\section{4 印刷条件}

·印刷機：Lithopia（三菱重工製）

·印刷速度 : $400 \mathrm{rpm}$ (約 $220 \mathrm{~m} / \mathrm{min}$ )

·乾燥条件 : 紙面温度 $125^{\circ} \mathrm{C}$ (一定)

- 印刷枚数 : 5,000 部

Table 1 Consideration of paper properties concerning with revers-image ghosting from the advice of printing industry

\begin{tabular}{l|l}
\hline \multicolumn{1}{c|}{$\begin{array}{l}\text { Commom opinions expressed by persons } \\
\text { in the printing industry }\end{array}$} & \multicolumn{1}{c}{ Related properties } \\
\hline $\begin{array}{l}\text { Gloss paper shows reverse-image ghosting easily } \\
\text { Thick paper is not likely to show reverse-image } \\
\text { ghosting }\end{array}$ & $\begin{array}{l}\text { smoothness } \\
\text { stiffness, air permeability }\end{array}$ \\
$\begin{array}{l}\text { Reverse-image ghosting is strongly influenced by ink } \\
\text { tack. }\end{array}$ & ink receptivity, oil absorptiveness, picking intensity \\
$\begin{array}{l}\text { Reverse-image ghosting is reduced by increasing of } \\
\text { damping water }\end{array}$ & water absorptiveness, hydrophiticity compound \\
$\begin{array}{l}\text { Reverse-image ghosting occurs with continuous } \\
\text { printing }\end{array}$ & elution of some of compound by damping water or ink \\
$\begin{array}{l}\text { Reverse-image ghosting disappears if the blanket is } \\
\text { washed }\end{array}$ & vehide \\
\end{tabular}




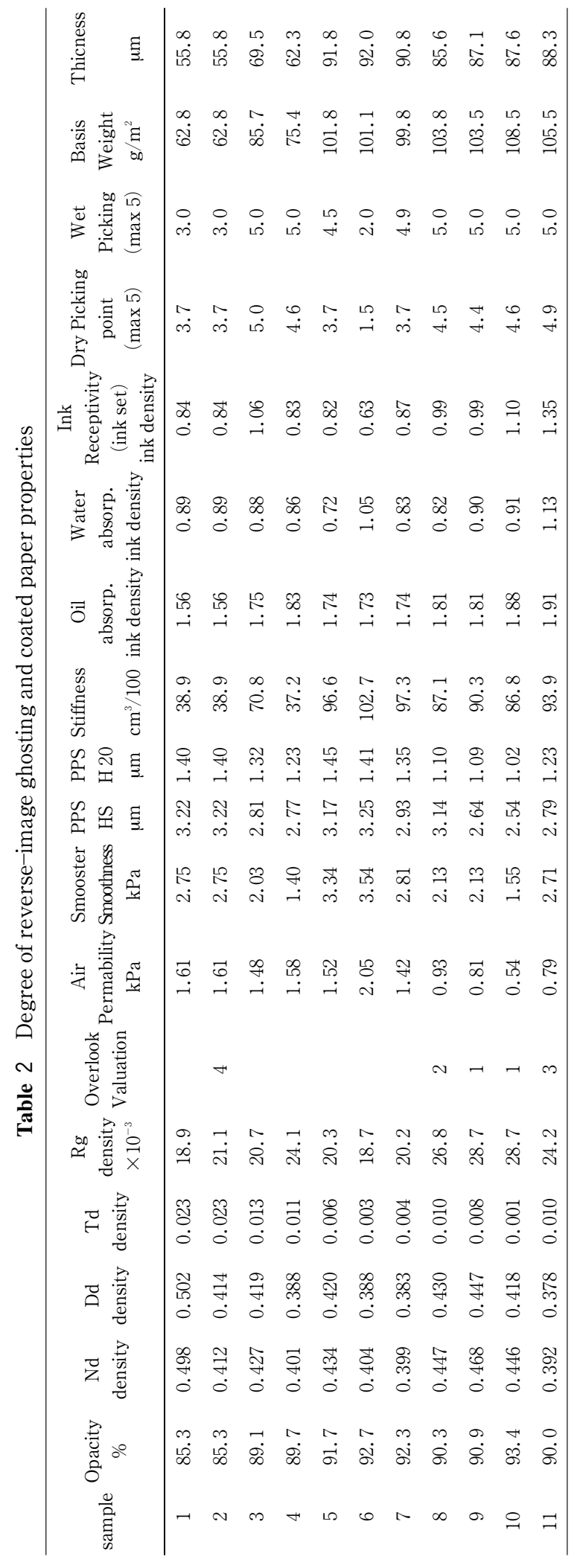


Table 3 Coating formulation and other characteristics of each coated paper

\begin{tabular}{|c|c|c|c|c|c|c|c|c|c|c|c|c|}
\hline Sample No. & & 1 & $2^{\mathrm{a}}$ & 3 & 4 & 5 & 6 & 7 & 8 & $9^{b}$ & $10^{c}$ & 11 \\
\hline GCC & $\begin{array}{c}\text { \%for total } \\
\text { pigment mass }\end{array}$ & 50 & 50 & 50 & 50 & 50 & 50 & 50 & 40 & 40 & 40 & 80 \\
\hline Kaoline Clay, Fine & $\begin{array}{c}\text { \%for total } \\
\text { pigment mass }\end{array}$ & 0 & 0 & 0 & 25 & 25 & 25 & 25 & 30 & 30 & 30 & 0 \\
\hline Kaoline Clay, Standard & $\begin{array}{c}\text { \% for total } \\
\text { pigment mass }\end{array}$ & 50 & 50 & 50 & 25 & 25 & 25 & 25 & 30 & 30 & 30 & 20 \\
\hline SBR Latex & $\begin{array}{c}\text { \% for total } \\
\text { pigment mass }\end{array}$ & 10 & 10 & 10 & 10 & 9 & 6 & 10 & 10 & 12 & 10 & 10 \\
\hline Phosphorylated Starch & $\begin{array}{c}\% \text { for total } \\
\text { pigment mass }\end{array}$ & 3 & 3 & 3 & 3 & 3 & 5 & 3 & 1.5 & 0 & 1.5 & 3 \\
\hline Insolubilizer & $\begin{array}{c}\text { \%for total } \\
\text { pigment mass }\end{array}$ & 0.5 & 0.5 & 0.5 & 0.5 & 0 & 0.5 & 1 & 0.5 & 0.5 & 0.5 & 0.5 \\
\hline Coating Weight & $\mathrm{g} / \mathrm{m}^{2}$ (total) & 20 & 20 & 30 & 30 & 30 & 30 & 30 & 30 & 30 & 30 & 30 \\
\hline Basis Weight & $\mathrm{g} / \mathrm{m}^{2}$ (total) & 64 & 64 & 90 & 75 & 102 & 101 & 100 & 104 & 104 & 109 & 106 \\
\hline $\begin{array}{l}\text { Linear Pressure of } \\
\text { Supercalendering }\end{array}$ & $\mathrm{kN} / \mathrm{cm}$ & 200 & 200 & 200 & 200 & 200 & 200 & 200 & 250 & 250 & 250 & 250 \\
\hline $\begin{array}{c}\text { Nips of } \\
\text { Supercalendering }\end{array}$ & times & 10 & 10 & 10 & 10 & 10 & 10 & 10 & 12 & 12 & 12 & 12 \\
\hline
\end{tabular}

Note. ${ }^{\text {a }}$ To confirm reptoducibility ; ${ }^{b}$ no hydrophilic materials ; ${ }^{c}$ pigmented base paper

・温湿度： $24^{\circ} \mathrm{C} \quad 65 \%$

・刷 版：デラミゴースト評価版

・ブランケット：MC $25 \mathrm{~V}$ (金陽社製)

・インキ：Web World Teras N タイプ (DIC 製),

タック $\rightarrow$ 墨 6.7 ,藍 7.2 , 紅 6.5 , 黄 6.2

·給湿液 : 水道水 $+\mathrm{NT}$ 液 (DIC 製), pH 5.6 6.0 管理

\section{5 印刷物評価方法}

印刷物のインキ濃度はコーサー濃度測定器を用いて 測定した。デラミゴーストは 5, 000 部目付近の印刷物 を無作為に 10 部取りだし，評価に用いた。デラミゴ ーストの目視判定は 5 点満点で行なった。目視判定は 差が目視ではっきり分かるサンプルに限定した。濃度 測定はデラミゴースト部分と通常部分を各 30 点測定 した。プリントスルーの影響濃度の測定数は各 10 点 とした。

RI 印刷試験機を用いてのインキセット性は次のよ うに評価した。まず， $0.7 \mathrm{ml}$ のシアンインキ $\left(\mathrm{Geos}^{-}\right.$ $\mathrm{G}, \mathrm{N}$ タイプ, DIC 製) を 3 番ロールで練り, 評価サ
ンプルで印刷後 30 秒経過時に 1 番ロールに張り付け た用紙と接触させ未乾燥インキを転写させた。転写用 紙のインキが乾燥後, コーサー濃度測定器を用いて濃 度を測定した。

\section{3. 結果と考察}

\section{1 デラミゴーストの評価方法}

デラミゴーストはインキ転写不良の一種であり, 発 生度合いは見た目に左右される。よって目視判定が重 要となるが, 微妙なケースでは目視判定が難しく, 塗 工紙の各種物性との関連を調查する場合を考えると, 主観に左右されない客観的な数值化が必要となる。そ こで，デラミゴースト発生度合いの数值化を試みた。

数值化はデラミゴースト部分と通常部分の濃度差を 発生度合いとする事が出来る。しかし, デラミゴース 卜はその性質上, 反対面に必ず高い濃度の印刷が存在 する（Fig. 2)。また，通常使用される印刷用紙に完全 に不透明なものはほとんどなく, デラミゴースト部分 の印刷濃度の測定は裏面印刷の影響を必ず受けてしま 
う。この影響を不透明度の值から補正する方法では, プリントスルーの影響が用紙によってまちまちである ため，補正しきれない。

そこで，各サンプルが反対面の印刷の影響をどの程 度受けるのかを実測し，その影響を濃度差からとり除 くこととした。具体的には下記式 1 の值をデラミゴー スト発生度合いとした。

$\mathrm{Rg}=\mathrm{Nd}-(\mathrm{Dd}-\mathrm{Td})$

ここで Rg はデラミゴースト発生度合い, $\mathrm{Nd}$ は通 常部分の印刷濃度，Dd はデラミゴースト部分の印刷 濃度, Td はプリントスルーの影響濃度である。プリ ントスルーの影響濃度は裏面に $100 \%$ の黒べタ印刷部 分の濃度を表面の白紙部分から測定した。プリントス ルーの影響濃度は白紙部分から測定しているため，印 刷がある部分とでは影響濃度が厳密な意味では異なる が，デラミゴーストの発生部分の印刷濃度は比較的薄 いため，この誤差は無視できるものとした。Fig. 5 は プリントスルーの影響を補正しなかった場合，Fig.6 は補正した場合であるが，明らかに補正した場合の方 が目視判定と一致し，おおむね妥当な評価方法と考え

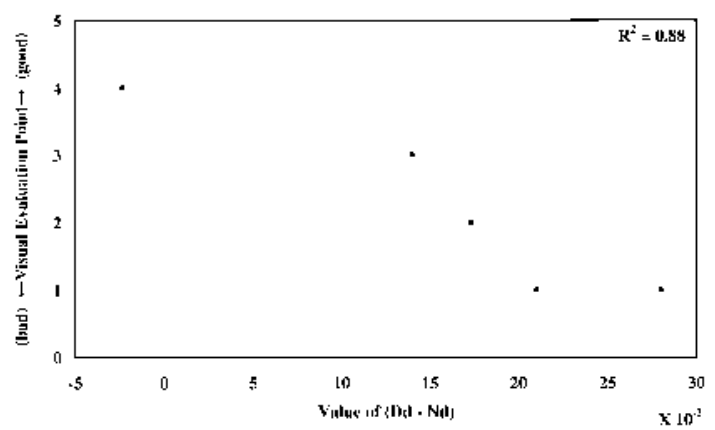

Fig. 5 Relationship between no corrected density difference and visual evaluation (Max:5).

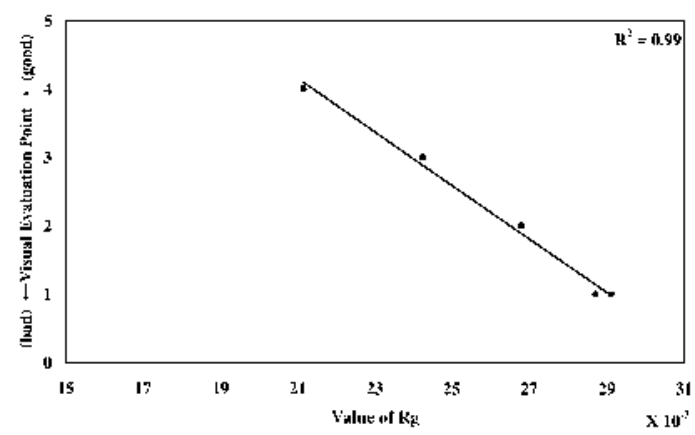

Fig. 6 Relationship between corrected density difference and visual evaluation (Max :5).
られる。以上の結果から，式(1)によりデラミゴースト 発生度合いを客観的に評価することが可能となった。

\section{2 デラミゴーストと用紙物性}

次に $\operatorname{Rg}$ の值と各種塗工紙物性との関係を調べた (Table 2)。結果, 相関が高かったのはスムースター 平滑度やプリント・サーフ表面粗さで表される平滑性 であった。平滑性が高いほどデラミゴーストは強く発 生していた。これは昔よりも近年の高平滑なグロス塗 工紙の方が発生頻度が高くなっていることと一致する。 種々の平滑性の中でもハードバッキングでの $20 \mathrm{kgf} /$ $\mathrm{cm}^{2}$ のプリント・サーフ表面粗さとの相関が高かった (Fig. 7)。プリント・サーフ表面粗さ測定時に用紙に 加えられている圧力と, オフ輪印刷において用紙が BC に加えられている圧力が近似していることを考え ると，この結果は非常に理にかなっていると言える。

コート紙表面の凹凸の大きさや, オフセット印刷に おけるインキ膜厚の関係（Fig. 8）から，圧縮下での 平滑性が高いと, 用紙と BC が密着しやすいことが推 察できる（Fig.9）。密着性が高いと, 用紙が BCに貼

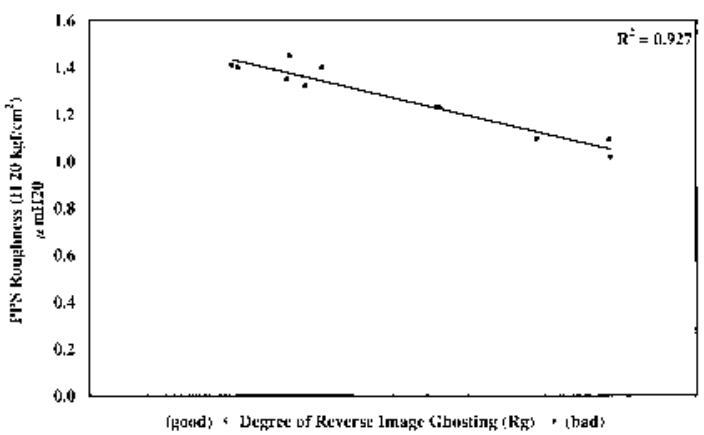

Fig.7 Relationship between reverse-image ghosting and PPS smoothness ( $\left.\mathrm{H} 20 \mathrm{kgf} / \mathrm{cm}^{2}\right)$.

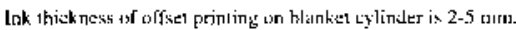

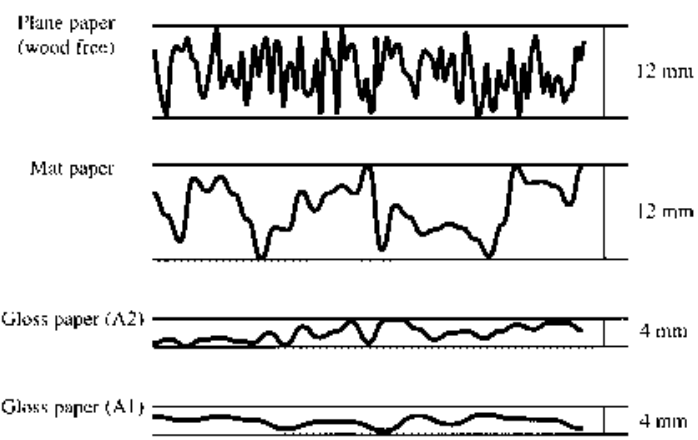

Fig. 8 Roughness of paper surface and ink thickness on blanket cylinder. 


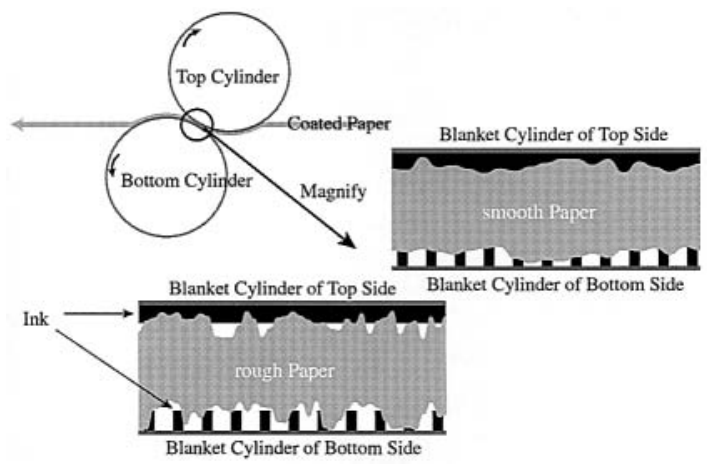

Fig. 9 Propose mechanism of smoothness effect on the improper web release.

り付きやすくなり，Fig. 1 に示した用紙の走行不良を 起こしやすくしていると言える。走行不良の発生が多 くなるためインキが $\mathrm{BC}$ 上に蓄積しやすいのか, 一回 の走行不良による用紙の剥離時間が長いためインキが 蓄積しやすいのか定かでないが，おそらくこれらが影 響しているのであろう。

ところで, 用紙の走行不良の発生頻度が同程度であ れば，インキに対する用紙物性の違いがデラミゴース トの発生に影響を与えることが予想できる。そこで, ハードバッキングでの $20 \mathrm{kgf} / \mathrm{cm}^{2}$ のプリント・サー フ表面粗さが同程度であるサンプルにしぼり, 相関を 調べた。その結果，インキセット性との間で比較的高 い相関が見られた。インキセットが遅いほど，デラミ ゴーストが強く発生している（Fig. 10）。インキセッ トが遅いと言うことは，インキの溶剤成分と固形分の 分離を起こす速度が小さいと言うことである3

これは紙とインキが接触した一瞬の間に不動化する インキ量が少なく, 単位時間当たりのインキ転移量が 少ないことを意味する。インキセット性は用紙の様々 な物性によって左右され, その速度の差とインキ転移 量の間に完全な比例関係が成り立たないことも考えら れが，インキ転移量の主要な要因と考えられる平滑度 については，プリント・サーフ表面粗さが同程度のも ののみを比較しているため, インキセット性以外の要 因は通常非常に軽微なものであり無視することができ る。用紙の走行が異常となり $\mathrm{BC}$ からの剥離が発生し ているときは用紙とインキとの接触時間が通常よりも 短い。その短い間でも多くインキを転写できる用紙は $\mathrm{BC}$ 上のインキの蓄積を抑え，デラミゴーストは発生 しにくいが，転写量が少ない用紙は蓄積を促進するた めデラミゴーストが発生しやすいのであろう。

ここで, 本研究において相関関係が認められなかっ

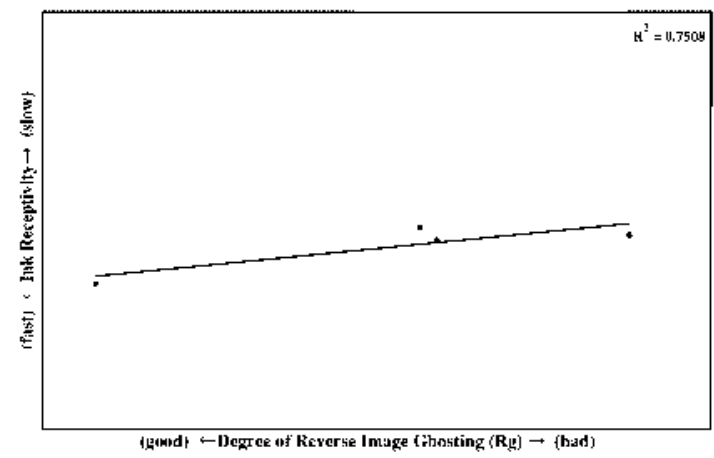

Fig. 10 Relationship between reverse-image ghosting and ink receptivity.

た他の要因について考察する。これまで湿し水によっ て溶け出す親水性物質が影響しているという説もあっ たが，親水性物質を完全に除いたサンプルにおいても デラミゴーストが発生し, さらにドライピック強度や ウエットピック強度とも相関がまったくなかった。ま たデラミゴースト発生時に BCに蓄積したインキ層を 分析したが, 塗工層由来の成分は一切検出されなかっ た。これらのことから，この説は完全に否定される。 実際，湿し水は少量であり，原紙層が吸収してしまう ので, 塗工層中の成分を溶解すると考えるには無理が ある。

次にこわさについて考察する。デラミゴーストの発 生機構を考えると，こわさは明らかに影響すると考え られる。しかし, 今回の試験範囲で相関は全く認めら れなかった。同様に, 坪量や厚みとも相関は認められ なかった。これは, 今回は比較的近い坪量の用紙を使 用したため, 差が見られなかったものと推察でき, 実 際には坪量の高い方が発生しにくいことは経験的に確 かめられている。今回使用した坪量でのこわさの差程 度ではデラミネーションに影響を及ぼさないのであろ

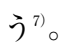

さらに透気度との関係では, 相関係数は 0.64 であ り, 他物性に比べると比較的相関が高い。しかし, 今 回はデーターを示していないが，相関が逆になった例 があり, 透気度は無関係であると思われる。透気度は 平滑性とある程度の相関を持つため, 今回の結果はそ のためと言える。

その他, 不透明度, 吸油性, 吸水性要因については デラミゴーストとの発生度合いとの間に相関は認めら れなかった。 


\section{4. ま と め}

従来より用紙の影響が示唆されながら，はっきりと したことが分かっていなかった用紙とデラミゴースト との関係を明らかにすることが出来た。

デラミゴーストの発生度合いは, プリントスルーの 影響を差し引いた濃度差で数值化でき, 正確に評価で きることが分かった。また, 親水性物質の溶出, ピッ ク強度, 小さなこわさの差はデラミゴースト発生の主 要因ではないことが確認できた。平滑性，特に印圧程 度の圧力がかかった状態での平滑性（プリント・サー フ表面粗さ）がデラミゴースト発生と相関関係が高か ったが，高い平滑性は用紙と BC が密着し，走行不良 を発生させやすいためと考えられる。プリント・サー フ表面粗さが同程度の場合は，インキセット性が関与 しており，セット性が高い用紙はインクの蓄積を防止 してデラミゴーストを起こしにくいと考えられる。以 上の結果は, 従来のデラミゴースト発生機構を用いて 矛盾なく説明できる。
今回は坪量の近似した A 2 A 3 のグロス紙にしほ って検討を行ったが，今後は更に様々な用紙を用いて 実験を行い，デラミゴーストに対する用紙の知見を集 める予定である。本研究の成果が印刷トラブルの防止 や防止できる用紙の開発に一役たてば幸いである。

\section{参考文献}

1）印刷出版研究所編集部：印刷情報（1）16（2000）

2）平版印刷技術一知識と実務一，日本印刷技術協会, 第 14 章, p 164

3）熟谷公人：日本印刷学会誌 39（6）40（2002）

4）藤田幸英, 井上信一：日本印刷学会第 106 回春期 研究発表会予稿集, 2001, p 29

5）熟谷公人，柴裕一，山根憲吾，藤田幸英：第 68 回紙パルプ研究発表会要旨集, 紙パルプ技術協会, 東京, 2001, p 122

6）藤田幸英, 井上信一：日本印刷学会誌３9 (2) 103 (2002)

（受理：’04.12.13） 